\title{
Health risk related to radon in a thermal spa utilizing waters from Guarani aquifer
}

\author{
D. M. Bonotto \& T. O. Santos \\ Departamento de Petrologia e Metalogenia, \\ Instituto de Geociências e Ciências Exatas-UNESP, Rio Claro, Brazil
}

\begin{abstract}
This investigation was carried out within the Paraná sedimentary basin, Brazil, involved the sampling of groundwater and air, and was realized with the purpose of evaluating the radioactivity, due to radon gas, in a thermal spa utilizing the waters from Guarani (Botucatu-Pirambóia) aquifer. The results reported here provide additional information relative to that of previous studies focusing on the presence of radionuclides in the aquifer, which have mainly characterized those belonging to uranium and thorium series decay, such as the uranium isotopes $\left({ }^{238} \mathrm{U}\right.$ and $\left.{ }^{234} \mathrm{U}\right)$, radium isotopes $\left({ }^{226} \mathrm{Ra}\right.$ and $\left.{ }^{228} \mathrm{Ra}\right)$, radon daughters $\left({ }^{214} \mathrm{Bi}\right.$ and ${ }^{214} \mathrm{~Pb}$ ) and radon $\left({ }^{222} \mathrm{Rn}\right)$ itself. The results obtained were compared with the maximum permissible concentration limits in air and drinking water defined by international standards, such as the guidelines for drinking water quality established by the World Health Organization. The possible processes responsible for the presence of radon in the aquifer were also considered in order to evaluate the data obtained.
\end{abstract}

Keywords: radon, air, groundwater, Guarani aquifer, thermal spa.

\section{Introduction}

Radon ( ${ }^{222} \mathrm{Rn}$, half-life 3.84 days) is a naturally occurring volatile noble gas formed from the normal radioactive decay series of ${ }^{238} \mathrm{U}$, according to the following decay sequence: ${ }^{238} \mathrm{U}(4.49 \mathrm{Ga}, \alpha) \rightarrow{ }^{234} \mathrm{Th}\left(24.1 \mathrm{~d}, \beta^{-}\right) \rightarrow{ }^{234} \mathrm{~Pa}(1.18$ $\left.\min , \beta^{-}\right) \rightarrow{ }^{234} \mathrm{U}(0.248 \mathrm{Ma}, \alpha) \rightarrow{ }^{230} \mathrm{Th}(75.2 \mathrm{Ka}, \alpha) \rightarrow{ }^{226} \mathrm{Ra}(1622$ a, $\alpha) \rightarrow$ ${ }^{222} \mathrm{Rn}(3.83 \mathrm{~d}, \alpha) \rightarrow{ }^{218} \mathrm{Po}(3.05 \mathrm{~min}, \alpha) \rightarrow \ldots$ It is a colorless, odorless, tasteless, chemically inert and radioactive gas produced continuously in rocks and soils through $\alpha$-decay of ${ }^{226} \mathrm{Ra}$, with some atoms escaping to the surrounding fluid 
phase, such as groundwater and air. It is subjected to recoil at "birth", with the emanated fraction relatively to that produced in the solid phase being dependent on factors such as total surface area of solids and concentration/distribution of ${ }^{238} \mathrm{U}\left({ }^{226} \mathrm{Ra}\right)$ in the minerals [1]. On the other hand, ${ }^{222} \mathrm{Rn}$ also generates several daughters (heavy metals) through a sequence decay that finishes with lead, i.e. ${ }^{222} \mathrm{Rn}(3.84 \mathrm{~d}, \alpha) \rightarrow{ }^{218} \mathrm{Po}(3.05 \mathrm{~min}, \alpha) \rightarrow{ }^{214} \mathrm{~Pb}\left(26.8 \mathrm{~min}, \beta^{-}\right) \rightarrow{ }^{214} \mathrm{Bi}(19.7$ $\left.\min , \beta^{-}\right) \rightarrow{ }^{214} \mathrm{Po}(0.16 \mathrm{~ms}, \alpha) \rightarrow{ }^{210} \mathrm{~Pb}\left(22.3 \mathrm{a}, \beta^{-}\right) \rightarrow{ }^{210} \mathrm{Bi}\left(5 \mathrm{~d}, \beta^{-}\right) \rightarrow{ }^{210} \mathrm{Po}$ $(138.4 \mathrm{~d}, \alpha) \rightarrow{ }^{206} \mathrm{~Pb}$.

High ${ }^{222} \mathrm{Rn}$ concentrations occur in groundwater in many areas where wells are used for domestic water supply and thermal spas, including small rural water supplies [2,3]. Exposure to radon and its progeny is believed to be associated with increased risks of several kinds of cancer [4]. When radon or its progeny are inhaled, lung cancer accounts for most of the total incremental cancer risk, while ingestion of radon in water is suspected of being associated with an increased risk of tumors of several internal organs, primarily the stomach [4]. Inhalation of radon progeny accounts for about $89 \%$ of the individual risk associated with domestic water use, with almost $11 \%$ resulting from directly ingesting radon in drinking water [4]. Several authors [5-11] also pointed out that although radon in water is not a well-documented health risk, it does contribute to radon in indoor air, which has been established as a health threat. Furthermore, high concentrations of ${ }^{222} \mathrm{Rn}$ in groundwater also indicate the presence of radon's parent nuclides, ${ }^{238} \mathrm{U}$ and ${ }^{226} \mathrm{Ra}$, in the water-rock system, which are known health risks when ingested in drinking water [12].

The knowledge of the geochemical and hydrogeological mechanisms that control the movement of ${ }^{222} \mathrm{Rn}$ through the groundwater system may be informative of the natural processes related to its high concentration associated with low transmissivity zones [13], with the uranium content of the source rock, severe chemical weathering, hydrothermal solution, deposition, or extensive fracturing [14], and with variations in stress in rocks associated with seismicity, where in some cases temporal variations have preceded large earthquakes [15-17].

Radon and decay product nuclei are present in indoor environments of spa facilities and have been identified as an agent of additional radiation burden both for bathers and working personnel [18, 19]. This additional burden has been studied by many researchers, resulting in the introduction of appropriate health regulations [19-21]. However, for the spa facilities existing in several areas in Brazil the measurements for radon and decay product nuclei indoors are incipient or non-existent. This is particularly true for the thermal spas utilizing waters of the huge Guarani aquifer located in the South American continent, which are extensively used for consuming purposes, among others. Thus, the aim of this paper is to evaluate the contribution of ${ }^{222} \mathrm{Rn}$ to the public exposure related to bathers utilizing the hot waters of a thermal spa located in Londrina city, Paraná State, Brazil. The implications of the data obtained in terms of health risks related to the presence of radon in water and air under the perspective of the actual international guidelines will also be discussed. 


\section{General features of the studied area}

The Guarani aquifer of Triassic-Jurassic age has continental dimensions, extending over some $950,000 \mathrm{~km}^{2}$ within the Paraná sedimentary basin, South America, and comprising southern Brazil (states of Mato Grosso, Mato Grosso do Sul, Goiás, Minas Gerais, São Paulo, Paraná, Santa Catarina and Rio Grande do Sul), eastern Paraguay, NW Uruguay and the northeastern extreme corner of Argentina (fig. 1).

The aquifer has an average thickness of $300-400 \mathrm{~m}$, and is composed of silty and shaly sandstones of fluvial-lacustrine origin (the Pirambóia and Rosário do Sul formations in Brazil and the Buena Vista formation in Uruguay), and variegated quartzitic sandstones accumulated by eolian processes under desertic conditions (the Botucatu formation in Brazil, Misiones formation in Paraguay, and Tacuarembó formation in Uruguay and Argentina) [22]. A thick basaltic package of the Serra Geral formation (up to $1,500 \mathrm{~m}$ ) overlies this aquifer, reducing its exposed areas in non-continuous elongated strips, 10-100 km wide, along the edges of the proper Paraná basin, where the longest strip stretches between the states of São Paulo and Santa Catarina, in Brazil. The aquifer overlies previous formations ranging from the igneous basement to the Paleozoic sediments of the Passa-Dois and Tubarão Groups, being covered by Cretaceous sediments of the Bauru-Caiuá formations.

The potentiometric surface of the water shows a significant proportion of its total area having artesian conditions [23], and recharge occurring by direct infiltration of rainwater in the outcrop area, which is about $98,000 \mathrm{~km}^{2}$ [24]. The percolating water moves from the phreatic exposed areas that surround the entire basin towards its central part, and, in spite of the great distances separating the existing exploitation centers, data obtained sporadically indicate hydraulic conductivity values of $10^{-4}-10^{-5} \mathrm{~m} / \mathrm{s}$, effective porosity values of $10-20 \%$, storage coefficient values of $10^{-3}-10^{-6}$ and average transmissivity of $10^{-3} \mathrm{~m}^{2} / \mathrm{s}$ [24]. The water is extensively used for drinking purposes, industrial activities and recreation (thermal swimming pools), with the yields of the wells varying from $10-150 \mathrm{~m}^{3} / \mathrm{h}$ (phreatic exposed parts) up to $300-1000 \mathrm{~m}^{3} / \mathrm{h}$ (confined artesian wells) [25].

\section{Materials and methods}

For the purpose of this investigation, the sampling was held in Londrina thermal spa situated at Londrina city, Paraná State, Brazil (fig. 1). The surface area of Londrina municipality is $1,651 \mathrm{~km}^{2}$ and its population is approximately 480,000 inhabitants (according to the 2004 census). The spa is $6 \mathrm{~km}$ away from the city center and started its operation in 1991. The hot waters of the spa come from a 960m-deep tubular well, whose main characteristics, and their waters characteristics, are reported in table 1 . The lithology cut by drilling corresponded to the Serra Geral Formation (0-846m), Botucatu Formation $(846-884 \mathrm{~m})$, and Pirambóia Formation (884-960m). 


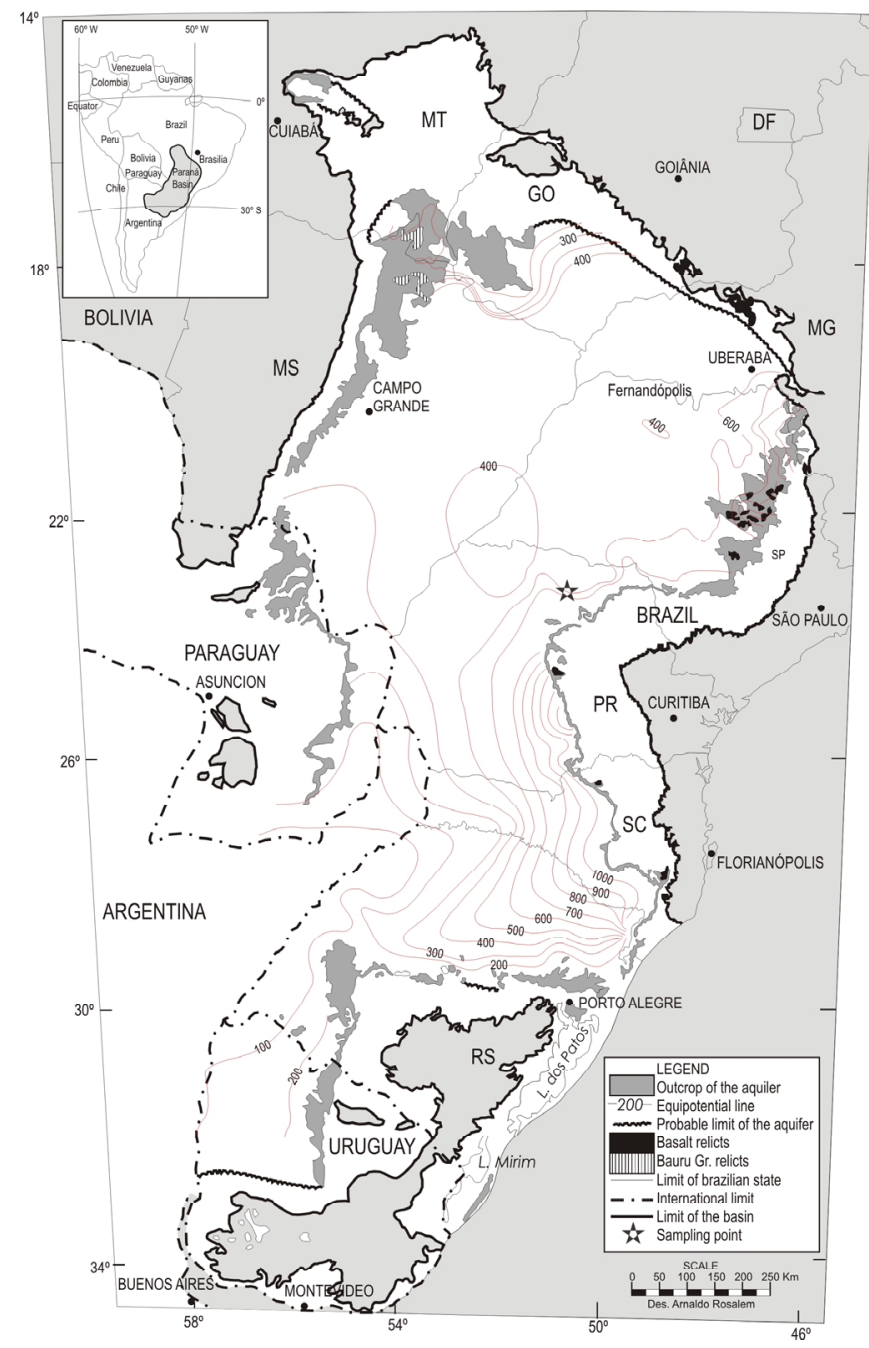

Figure 1: The outcrop of the Guarani aquifer at the Paraná sedimentary basin [22] and location of the sampling point for radon analyses.

The sampling campaign for radon analyses was performed between $23^{\text {rd }}$ (18:50h) and $24^{\text {th }}(10: 30 \mathrm{~h})$ November 2006 . The spa has facilities for immersion baths and the measurements were conducted in the room containing a bath (dimensions $=3.18-\mathrm{m}$ long, 2.12-m wide, and 1-m deep) that receives the hottest water at a rate of $\sim 0.4 \mathrm{l} / \mathrm{s}$. The size of the room is approximately $6-\mathrm{m}$ long, $4-\mathrm{m}$ wide, and $4 \mathrm{~m}$-high, yielding a volume of about $100 \mathrm{~m}^{3}$. The water temperature in the hottest bath varied between 42 and $45^{\circ} \mathrm{C}$ during this study, whereas the air temperature ranged from 26 up to $36^{\circ} \mathrm{C}$. 
Table 1: Description of the tubular well drilled at the Londrina thermal spa, Londrina city, Brazil, and chemical analyses of groundwater performed by [26].

\begin{tabular}{ccc}
\hline \multicolumn{3}{c}{ Description } \\
\hline Parameter & Unit & Value \\
\hline Altitude of the top & $\mathrm{m}$ & 450 \\
Latitude & - & $23^{\circ} 19^{\prime} 21^{\prime \prime} \mathrm{S}$ \\
Longitude & - & $51^{\circ} 09^{\prime} 49^{\prime \prime} \mathrm{W}$ \\
Total length & $\mathrm{m}$ & 960 \\
Geostatic pressure & bar & 224.8 \\
\hline
\end{tabular}

\begin{tabular}{ccc|ccc}
\hline \multicolumn{7}{c}{ Water analysis - Date of sampling $=\mathbf{0 1 / 1 6 / 2 0 0 4}$} \\
\hline Parameter & Unit & Value & Parameter & Unit & Value \\
\hline Chemical oxygen demand & $\mathrm{mg} / 1$ & $<1$ & Fluoride & $\mathrm{mg} / \mathrm{l}$ & 2.0 \\
Biochemical oxygen demand & $\mathrm{mg} / 1$ & $<1$ & Nitrate & $\mathrm{mg} / 1$ & $<0.04$ \\
$\mathrm{pH}$ & - & 9.48 & Nitrite & $\mathrm{mg} / 1$ & $<0.01$ \\
Conductivity at $25^{\circ} \mathrm{C}$ & $\mu \mathrm{S} / \mathrm{cm}$ & 470 & Sodium & $\mathrm{mg} / 1$ & 105 \\
Total alkalinity & $\mathrm{mg} / 1$ & 164.3 & Potassium & $\mathrm{mg} / 1$ & 0.8 \\
Total hardness & $\mathrm{mg} / 1$ & 2.1 & Calcium & $\mathrm{mg} / 1$ & 0.7 \\
Silica & $\mathrm{mg} / 1$ & 47.2 & Magnesium & $\mathrm{mg} / 1$ & 0.07 \\
Total Kjeldahl Nitrogen & $\mathrm{mg} / 1$ & $<0.01$ & Total iron & $\mathrm{mg} / 1$ & $<0.01$ \\
NH $3_{3}$-Nitrogen & $\mathrm{mg} / 1$ & $<0.01$ & Aluminum & $\mathrm{mg} / 1$ & $<0.1$ \\
Organic-Nitrogen & $\mathrm{mg} / 1$ & $<0.01$ & Barium & $\mathrm{mg} / 1$ & $<0.5$ \\
Dry residue at $103^{\circ} \mathrm{C}$ & $\mathrm{mg} / 1$ & 308 & Cadmium & $\mathrm{mg} / 1$ & $<0.01$ \\
Total Suspended Solids & $\mathrm{mg} / 1$ & $<5$ & Lead & $\mathrm{mg} / 1$ & $<0.05$ \\
Bicarbonate & $\mathrm{mg} / 1$ & 89.4 & Total chromium & $\mathrm{mg} / 1$ & $<0.06$ \\
Carbonate & $\mathrm{mg} / 1$ & 54.6 & Copper & $\mathrm{mg} / 1$ & $<0.01$ \\
Sulphate & $\mathrm{mg} / 1$ & 52 & Manganese & $\mathrm{mg} / 1$ & $<0.01$ \\
Chloride & $\mathrm{mg} / 1$ & 14.2 & Zinc & $\mathrm{mg} / 1$ & $<0.01$ \\
\hline
\end{tabular}

Water and air radon concentrations were measured using an Alpha Guard PQ2000PRO (Genitron $\mathrm{GmbH}$ ) equipped with an appropriate unit (Aquakit), following a protocol proposed by the manufacturer [27]. Alpha Guard is an ionizing chamber that measures radon via alpha spectrometric techniques. For measurement with Aquakit, the water samples were forced to degas their radon content within a radon tight assembly, which consists of two glass vessels and the Alpha Guard unit. Alpha Guard monitored indoor radon in 1 min data sampling cycles simultaneously with air temperature. The indoor measurements were performed without interfering in the operation procedure of the spa, as about 20 bathers utilized the facilities for immersion baths during the experiments.

The determination of the radon concentration in the water samples through the Aquakit unit was based on the Rn-concentration indicated on the Alpha Guard radon monitor and on the use of the following equation:

$$
1000 \mathrm{c}_{\mathrm{w}}=\mathrm{c}_{\mathrm{a}} \times\left[\mathrm{k}+\left(\mathrm{V}_{\mathrm{sy}}-\mathrm{V}_{\mathrm{sa}}\right) / \mathrm{V}_{\mathrm{sa}}\right]-\mathrm{c}_{0}
$$

where: $\mathrm{c}_{\mathrm{w}}=\mathrm{Rn}$-concentration in water sample $(\mathrm{Bq} / \mathrm{l}) ; \mathrm{c}_{\mathrm{a}}=$ radon concentration $\left(\mathrm{Bq} / \mathrm{m}^{3}\right)$ in the measuring set-up after expelling the radon (indicated by Alpha Guard); $\mathrm{c}_{0}=$ radon concentration $\left(\mathrm{Bq} / \mathrm{m}^{3}\right)$ in the measuring set-up before 
sampling (zero level, i.e. $0 \mathrm{~Bq} / \mathrm{m}^{3}$ ); $\mathrm{V}_{\mathrm{sy}}=$ interior volume of the measurement set-up $(1122 \mathrm{ml}) ; \mathrm{V}_{\mathrm{sa}}=$ volume of the water sample $(100 \mathrm{ml}) ; \mathrm{k}=$ radon distribution coefficient between a watery phase and the air volume existing above $\left(0.16\right.$ for temperatures between 40 and $\left.45^{\circ} \mathrm{C}\right)$.

Four water samples $(1 \mathrm{~kg})$ were also stored in glass bottles fitted with inlet and outlet stopcocks, conducted up to the laboratory, and subjected to a technique for quantifying ${ }^{222} \mathrm{Rn}$ based on the emanation procedure [28] and consisting of the 1) removal of radon from the sample, 2) transfer of radon to a scintillation flask, and 3) detection of radon by scintillation counting. The purpose of this sampling was to compare radon concentration data obtained by different methods.

\section{Results and discussion}

The thermal water radon measurement performed with Alpha Guard yielded an average value of $2.2 \mathrm{~Bq} / \mathrm{l}$, whilst the concentration varied between 0.06 and 5.9 $\mathrm{Bq} / \mathrm{l}$ (average $=3.5 \mathrm{~Bq} / \mathrm{l}$ ) according to the data acquisition by scintillation counting. Future investigations are necessary to investigate if the differences are systematic, as they could indicate the need of recalibration of the system based on scintillation counting. Potential health hazards from radon in consuming water have been considered worldwide, with many countries adopting the guideline activity concentration of $100 \mathrm{~Bq} / 1$ for drinking water quality recommended by [29]. The radon concentrations of the thermal waters from Londrina thermal spa vary, but, despite this, are greatly below the $100 \mathrm{~Bq} / 1$ WHO limiting value. In addition, the thermal waters of the spa only occasionally are utilized for consuming purposes, as their main use is for bathing/recreation and, consequently, the health risk due to their ingestion is practically absent.

Figure 2 shows the variability of the indoor radon concentration in the room of the spa for immersion baths as evaluated by Alpha Guard in $24^{\text {th }}$ November 2006 from 7:04 to 7:23 am. The average value corresponded to $71.4 \mathrm{~Bq} / \mathrm{m}^{3}$, which was higher than the mean values of 19.6 and $17.2 \mathrm{~Bq} / \mathrm{m}^{3}$ obtained, respectively, in the counting room of LABIDRO-Laboratory of Isotopes and Hydrochemistry (fig. 3), where the scintillation measurements were performed, and in LITOTECA (fig.4), that is a large room of DPM-Department of Petrology and Metallogeny utilized for storing different rock types with variable content of natural radionuclides.

The mechanisms which can cause ${ }^{222} \mathrm{Rn}$ release from the solid phase and consequently account for the observed Rn content of groundwater and air were discussed elsewhere $[30,31]$ and consists basically of the following processes: ${ }^{222} \mathrm{Rn}$ recoil following alpha-decay of ${ }^{226} \mathrm{Ra}$ atoms close to the surface of the solid particles (within the ${ }^{222} \mathrm{Rn}$ recoil range of $0.036 \mu \mathrm{m}$ ); ${ }^{222} \mathrm{Rn}$ diffusion through the crystalline lattice from production sites below the rock surface, ${ }^{222} \mathrm{Rn}$ diffusion along crystal defects, grain boundaries or microfractures from greater depths below the rock surface; existence of a network of $100-200 \AA$ wide nanopores in rocks and minerals, many of which intersect the grain surface, and give rise to a large internal surface area of the solids (in the range of about $10 \mathrm{~m}^{2}$ 
per $\mathrm{cm}^{3}$ ), orders of magnitude higher than the external surface calculated from grain size. Thus, the models developed for explaining the generation of radon in rocks and transfer to air and water have followed a more macroscopic approach [32] or have included many parameters that are difficult/impossible to measure practically, for instance, microscopic properties such as the surface roughness or inhomogeneous ${ }^{226} \mathrm{Ra}$ distribution in the solid [31, 33].

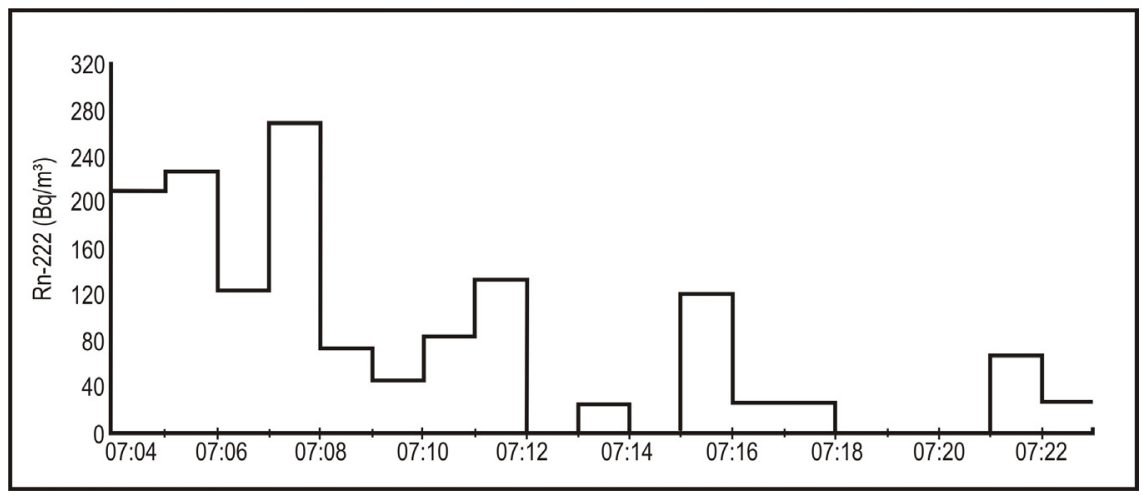

Figure 2: Characteristic variation of the indoor radon concentration in the room of the Londrina thermal spa for immersion baths. Date of the measurement: $24^{\text {th }}$ November 2006.

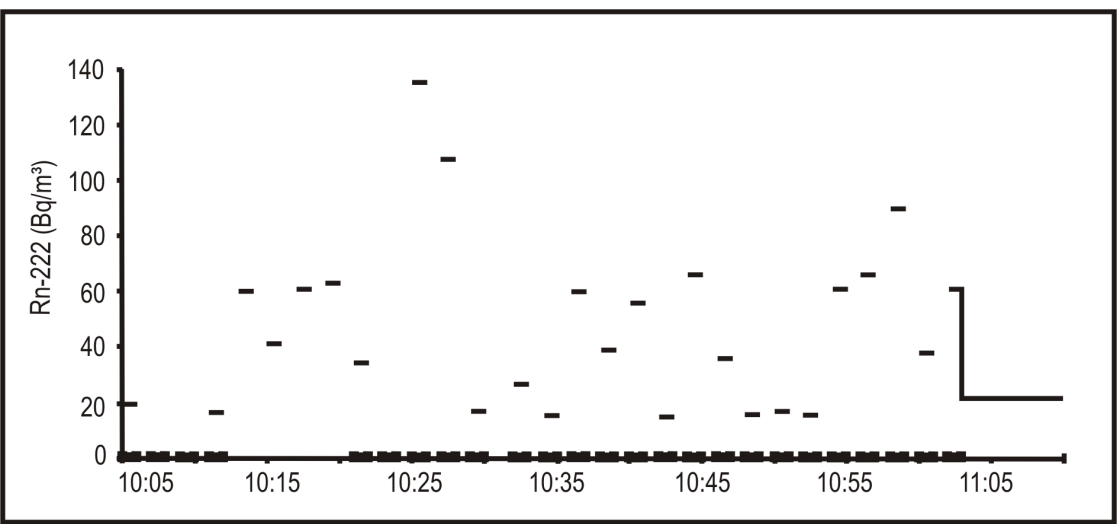

Figure 3: Characteristic variation of the indoor radon concentration in the counting room of LABIDRO, UNESP, Rio Claro. Date of the measurement: $15^{\text {th }}$ December 2006 .

The optimized action levels relating to chronic exposure involving radon in dwellings should, in most situations, fall within a yearly average concentration of 200 to $600 \mathrm{~Bq} / \mathrm{m}^{3}$ of ${ }^{222} \mathrm{Rn}$ in air [34]. On the other hand, the action level for remedial action relating to chronic exposure situations involving radon in workplaces is a yearly average concentration of $1000 \mathrm{~Bq} / \mathrm{m}^{3}$ of ${ }^{222} \mathrm{Rn}$ in air [34]. 
Therefore, the average indoor radon concentration of $71.4 \mathrm{~Bq} / \mathrm{m}^{3}$ in Londrina thermal spa is much lower than these limiting guideline values and, consequently, the inhalation of this gas is not a significant radiation burden both for bathers and working personnel of the spa.

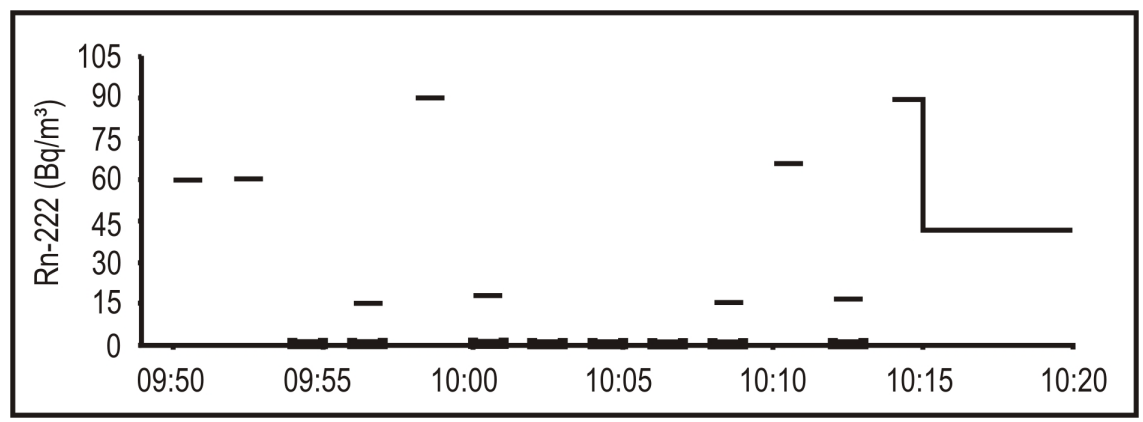

Figure 4: Characteristic variation of the indoor radon concentration in LITOTECA, UNESP, Rio Claro. Date of the measurement: $22^{\text {nd }}$ December 2006.

As a conclusion, bathing and working in Londrina thermal spa does not impose any health risk related to the ingestion of radon in water and inhalation of radon in air both to bathers and personnel. However, this scenario may not be the same in other thermal spas utilizing the waters of Guarani aquifer, because intense variations of radon concentration have been previously identified [28]. Thus, further investigations in the aquifer are highly recommended in order to raise the radiometric data base to levels equivalent to those existing in more developed countries.

\section{References}

[1] Flügge, S. \& Zimens, K.E., Die bestimmung von korngrossen und diffusionkonstanten aus dem emaniervermogen (Die theorie der emaniermethode). Zeitschrift fur Physikalische Chemie, B42, pp. 179-220, 1939.

[2] Petrie, A.S. \& Cram, A.G., Design implications of the distribution of pollutants in collection and storage systems used in small rural water supplies. Water Pollution V: Modelling, Measuring and Prediction, eds. P. Anagnostopoulos \& C.A. Brebbia, WIT Press: Southampton, pp. 503512, 1999.

[3] Vogiannis, E., Nikolopoulos, D., Louizi, A. \& Halvadakis, C.P., Radon variations during treatment in thermal spas. J. Environ. Radioactivity, 75, pp. 159-170, 2004.

[4] USEPA (United States Environmental Protection Agency), Radon in drinking water health risk reduction and cost analysis. Federal Register 64, Washington, pp. 9559-9599, 1999. 
[5] Gesell, T.F. \& Prichard, H.M., The technologically enhanced natural radiation environment. Health Phys., 28, p. 361, 1975.

[6] Gesell, T.F. \& Prichard, H.M., The contribution of radon in tap water to indoor radon concentrations. The Natural Radiation Environment III, eds. T.F. Gesell \& W.M. Lowder, Proc. Symp., USDOE, Houston, Rep. Conf. 780422, 1, pp. 5-56, 1980.

[7] Partridge, J.E., Horton, T.R. \& Sensintaffer, E.L., A study of radon-222 released from water during typical household activities. U.S. Environmental Protection Agency Tech. Note, ORP/EERF-79-1, 1979.

[8] Bruno, R.C., Sources of indoor radon in houses: a review. J. Air Pollut. Control Assoc., 33, pp. 105-109, 1983.

[9] Prichard, H.M., The transfer of radon from domestic water to indoor air. $J$. Am. Water Works Assoc., 79, pp. 159-161, 1987.

[10] Nazaroff, W.W. \& Nero, A.V. Jr., Radon and its decay products in indoor air, John Wiley \& Sons: New York, 1988.

[11] Nazaroff, W.W., Doyle, S.M., Nero, A.V. Jr. \& Sextro, R.G. Radon entry via potable water. Radon and its decay products in indoor air, eds. W.W. Nazaroff \& A.V. Nero Jr., John Wiley \& Sons: New York, 1988.

[12] Aieta, E.M., Singley, J.E., Trussel, A.R., Thorbjarnarson, K.W. \& McGuire, M.J., Radionuclides in drinking water: an overview. $J$. Am. Water Works Assoc., 79, pp. 144-152, 1987.

[13] Lawrence, E.P., Poeter, E. \& Wanty, R.B., Geohydrologic, geochemical, and geologic controls on the occurrence of radon in ground water near Conifer, Colorado, USA. J. Hydrol., 127, pp. 367-386, 1991.

[14] Nelson, P.H., Rachiele, R. \& Smith, A., Transport of radon in flowing boreholes at Stripa, Sweden. J. Geophys. Res., 88, pp. 2395-2405, 1983.

[15] Shishkevich, C., Earthquake related variation of micro-components in thermal water of the Tashkent aquifer. Geosci. Bull. Ser. A, 2, pp. 69-91, 1971.

[16] Wollenberg, H.A., Smith, A.R., Mosier, D.F., Flexser, S. \& Clark, M., Radon-222 in groundwater of the long valley caldera, California. Pageoph., 122, pp. 327-339, 1984.

[17] Smith, A.R., Bowman, H.R., Mosier, D.F. \& King, C.Y., Investigation of radon-222 in subsurface waters as an earthquake predictor. IEEE Trans. Nucl. Sci., NS-23, pp. 694-698, 1976.

[18] Steinhäusler, F., Radon spas: source term, doses and risk assessment. Radiation Protection Dosimetry, 24, pp. 257-259, 1988.

[19] Datye, V.K., Hopke, K., Fitzgerald, B. \& Raunemaa, A., Dynamic model for assessing Rn-222 and progeny exposure from showering with radonbearing water. Environmental Science and Technology, 31, pp. 15891596, 1997.

[20] Bernhardt, G.P. \& Hess, C.T., Acute exposure from Rn-222 and aerosols in drinking water. Environmental International, 22, pp. S753-S759, 1996.

[21] Fitzgerald, B., Hopke, K., Datye, V.K., Raunemaa, A. \& Kuuspalo, K., Experimental assessment of the short- and long-term effects of Rn-222 from domestic shower water on the dose burden incurred in normally 
occupied homes. Environmental Science and Technology, 31, pp. 18221829, 1997.

[22] Araújo, L.M., França, A.B. \& Potter, P.E., Giant Mercosul aquifer of Brazil, Argentina, Uruguay and Paraguay: hydrogeologic maps of Botucatu, Pirambóia, Rosário do Sul, Buena Vista, Misiones and Tacuarembó Formations. Proc. of the $9^{\text {th }}$ National Meeting of Welldrillers, Universidade Federal do Paraná: Curitiba, pp. 1-16, 1995.

[23] Rebouças, A.C., Groundwater in Brazil. Episodes, 11, pp. 209-214, 1988.

[24] Kimmelmann e Silva, A.A., Rebouças, A.C. \& Santiago, M.M.F., ${ }^{14}$ C analyses of groundwater from the Botucatu aquifer system in Brazil. Radiocarbon, 31, pp. 926-933, 1989.

[25] Gilboa, Y., Mero, F. \& Mariano, I.B., The Botucatu aquifer of South America, model of an untapped continental aquifer. J. Hydrol., 29, pp. 165-179, 1976.

[26] Hindi, E., Physical-chemical analysis of waters from Londrina thermal spa. Universidade Federal do Paraná: Curitiba, 2004.

[27] Genitron Instruments, Alpha Guard PQ2000/MC50, Multiparameter Radon Monitor, Genitron Instruments: Frankfurt, 2000.

[28] Bonotto, D.M. \& Caprioglio, L. Radon in groundwaters from Guarani aquifer, South America: environmental and exploration implications. Applied Radiation and Isotopes, 57, pp. 931-940, 2002.

[29] WHO (World Health Organization), Guidelines for drinking water quality: radiological aspects, available at http:www.who.int/water_sanitation_health/dwq/gdwq3/en/, 2004.

[30] Andrews, J.N. \& Wood, D.F. Mechanism of radon release in rock matrices and entry into groundwaters. Inst. Mineral. Metal. Trans., B81, pp. 198-209, 1972.

[31] Rama \& Moore, W.S., Mechanism of transport of U-Th series radioisotopes from solids into groundwater. Geochim. Cosmochim. Acta, 48, pp. 395-399, 1984.

[32] Andrews, J.N. \& Lee, D.J., Inert gases in groundwater from the Bunter Sandstone of England as indicators of age and palaeoclimatic trends. $J$. Hydrol., 41, pp. 233-252, 1979.

[33] Krishnaswami, S. \& Seidemann, D.E. Comparative study of ${ }^{222} \mathrm{Rn},{ }^{40} \mathrm{Ar}$, ${ }^{39} \mathrm{Ar}$ and ${ }^{37} \mathrm{Ar}$ leakage from rocks and minerals: implications for the role of nanopores in gas transport through natural silicates. Geochim. Cosmochim. Acta, 52, pp. 655-658, 1988.

[34] IAEA (International Atomic Energy Agency) International basic safety standards for protection against ionizing radiation and for the safety of radiation sources, Safety Series 115, Vienna, 353 pp., 1996. 